\title{
PENGALOKASIAN BIAYA BERSAMA DALAM PENENTUAN HARGA POKOK PRODUKSI PADA UD. BALI BUSANA GARMENT TAHUN 2016
}

\author{
Fitri Puspitasari \\ Jurusan Pendidikan Ekonomi, Fakultas Ekonomi \\ Universitas Pendidikan Ganesha Singaraja, \\ Indonesia \\ email :fi_threepuspitasari20@yahoo.com
}

\begin{abstract}
Abstrak
Penelitian ini bertujuan untuk mengetahui penerapan metode pengalokasian biaya bersama dalam menentukan harga pokok produksi pada UD. Bali Busana Garment pada tahun 2016. Subyek dalam penelitian ini adalah perusahaan UD. Bali Busana Garment, sedangkan obyek penelitian ini adalah penerapan alokasi biaya bersama dalam menentukan harga pokok produksi. Penelitian ini menggunakan teknik analisis deskriptif kuantitatif. Metode pengumpulan data yang digunakan dalam penelitian ini menggunakan dokumentasi. Hasil penelitian penerapan pengalokasian biaya bersama dapat dilakukan pada UD. Bali Busana Garment karena sudah terdapat tiga unsur biaya bersama yaitu biaya bahan baku, biaya tenaga kerja dan biaya overhead pabrik. Setelah diketahui besarnya biaya bahan baku, biaya tenaga kerja dan biaya overhead pabrik sesungguhnya, maka dapat dihitung seluruh biaya bersama yang dikeluarkan kepada ketiga produk yaitu singlet, jaket dan top, sehingga diperoleh perbedaan harga pokok dari masing-masing produk per bulannya pada tahun 2016 .
\end{abstract}

Kata kunci : biaya bersama, harga pokok produksi, pengalokasian biaya bersama.

\begin{abstract}
This research aims to determine the application of joint cost allocation methods in determining the cost of goods manufactured at UD. Bali Busana Garment in 2016. The subject in this research is UD. Bali Busana Garment, while the object of this research is the application of joint cost allocation in determining the cost of goods manufactured. This research uses quantitative descriptive analysis technique. Data collection methods used in this research using documentation. The results of reseach applying of joint cost allocation can be done at UD. Bali Busana Garment because there are already three elements of the joint cost, there are material cost, direct labor and overhead costs. After knowing of material cost, direct labor and overhead costs it can be calculated all joint costs incurred to the three products of the singlet, jacket and top, so that obtained difference of each product a month in 2016 .
\end{abstract}

Keywords: Joint cost, cost of goods manufactured, joint cost allocation.

\section{PENDAHULUAN}

Dalam menghitung harga pokok produksi dibutuhkan perhitungan secara tepat dan akurat. Penetapan harga pokok produksi sangat penting dilakukan oleh perusahaan karena memberikan informasi, salah satunya dalam menentukan harga jual suatu produk (Mulyadi, 2009). Setiap perusahaan tidak akan lepas dalam proses penentuan harga pokok. Penentuan harga pokok ini sangat penting untuk mengetahui apakah produk yang ditawarkan dapat memberikan laba atau tidak. Untuk mengetahui lebih jelas apa yang dimaksud dengan harga pokok, berikut ini dikutip dari para ahli. Menurut Bastian dan Nurlela (2010:49) harga pokok produksi adalah "kumpulan biaya produksi yang terdiri dari bahan baku langsung, tenaga kerja langsung dan biaya overhead pabrik ditambah persediaan produk dalam proses awal dan dikurang persediaan produk dalam proses akhir". Menurut Hanggana (2006), harga pokok produksi adalah semua biaya yang dikeluarkan untuk membuat satu unit barang jadi yang 
meliputi biaya bahan baku, biaya tenaga kerja langsung, dan biaya overhead pabrik. Harga pokok produksi menurut Winwin dan Ilham (2008) yaitu biaya barang yang telah diselesaikan selama satu periode. Menurut Kuswadi (2008:49) untuk perusahaan pabrik, harga pokok produksi adalah "semua biaya yang dikeluarkan untuk memproduksi suatu barang (jasa) jualan selama periode yang bersangkutan".

Manfaat harga pokok produksi bagi perusahaan memegang peranan yang sangat penting untuk kelangsungan hidup perusahaan. Adapun manfaat penentuan harga produksi yang dikemukakan oleh Mulyadi (2009) dan Widilestariningtyas, dkk (2012) adalah sebagai berikut. Pertama menentukan harga jual, kedua memantau realisasi biaya produksi, ketiga menghitung laba atau rugi periodic, keempat untuk menentukan harga pokok persediaan produk jadi dan produk dalam proses yang disajikan dalam neraca.

Elemen-elemen harga pokok produksi merupakan elemen-elemen biaya yang berhubungan dengan harga pokok. Elemen harga pokok produksi menurut Sugiri (2010) dan Prasetyo (2012) biaya utama yang mempengaruhi harga pokok produksi diantaranya adalah. Pertama biaya bahan baku, biaya bahan baku merupakan bahan yang membentuk bagian menyeluruh produk jadi. Kedua biaya tenaga kerja langsung, biaya tenaga kerja adalah harga yang dibebankan untuk penggunaan tenaga kerja manusia tersebut. Ketiga biaya overhead pabrik, biaya overhead pabrik adalah biaya produksi selain biaya bahan baku dan biaya tenaga kerja langsung.

Dalam melakukan produksi perusahaan tidak terlepas dari pengeluaran biaya-biaya guna menambah nilai barang secara ekonomis. Menurut Widilestariningtyas dkk (2012:10) pengertian biaya ada dua yaitu dalam arti luas biaya adalah "pengorbanan sumber ekonomi, yang diukur dalam satuan uang, yang terjadi atau yang kemungkinan akan terjadi untuk tujuan tertentu". Dalam arti sempit biaya dapat diartikan "sebagai pengorbanan sumber ekonomi untuk memperoleh aktiva. Menurut Gilarso (2003:125) biaya diartikan "semua pengorbanan yang perlu untuk suatu proses produksi, dinyatakan dalam uang menurut harga pasar yang berlaku". Fuad dkk (2006:153) berpendapat bahwa biaya yaitu "satuan nilai yang dikorbankan dalam suatu proses produksi untuk mencapai suatu hasil produksi". Menurut Dunia dan Wasilah (2014:22) biaya (cost) adalah "pengeluaran-pengeluaran atau nilai pengorbanan untuk memperoleh barang atau jasa yang berguna untuk masa yang akan datang, atau mempunyai manfaat melebihi satu periode akuntansi". Menurut Witjaksono (2013:12) biaya adalah "suatu pengorbanan sumber daya ekonomi untuk mencapai tujuan tertentu",

Dalam membebankan biaya produksi perusahaan harus adil, dan diharapkan menggunakan biaya yang efektif dalam mengalokasikan biayanya. Tujuan dari alokasi biaya untuk memberikan informasi kepada manajemen dalam penyusunan laporan keuangan maupun kepentingan dalam mengambil keputusan (Mursyidi, 2010). Biaya-biaya yang telah dikeluarkan untuk suatu produksi dapat diartikan sebagai harga pokok dari produk itu sendiri. Apabila selama proses produksi dihasilkan lebih dari satu produk maka biaya tersebut disebut dengan biaya bersama (joint cost) yang telah dikeluarkan untuk memproduksi produk-produk yang bersangkutan.

Menurut Mursyidi (2010:159) biaya bersama (joint cost) atau dikenal juga dengan biaya produksi bersama (joint production cost) adalah "biaya produksi yang terdiri dari bahan baku, tenaga kerja langsung dan biaya overhead pabrik yang sama dalam satu kali proses produksi menghasilkan berbagai jenis produk utama". Jenisjenis produk yang dihasilkan tersebut dapat dibedakan berdasarkan kualitas, 
bentuk fisik, sifat, dan lain sebagainya, sedangkan menurut Raiborn dan Michael (2011:64) "biaya yang dikeluarkan untuk bahan, tenaga kerja, dan kelebihan selama proses bersama disebut sebagai biaya bersama (joint cost) dari proses produksi".

$$
\text { Menurut }
$$

Widjajatunggal

(1997:277) biaya bersama adalah "biaya-biaya material langsung, upah langsung, dan overhead pabrik. Mereka terjadi sampai suatu titik dalam proses produksi, disebut "split-off-point" yaitu produk individual berpisah". Pada splitoff point, mungkin ada biaya pemerosesan tambahan (sebagai tambahan terhadap biaya bersama). Yang termasuk dalam biaya pemrosesan tambahan bisa material langsung, upah langsung, dan overhead pabrik. Semua terjadi pada produk yang diidentifikasikan secara khusus. Kesulitan dengan biaya bersama adalah bahwa mereka tidak dapat memisahkan secara khusus diidentifikasikan dengan setiap produk yang secara simultan diproduksi dan biaya bersama harus dialokasikan ke setiap produk bersama.

Menurut Maher dan Deakin (1997:291) biaya gabungan (joint cost) adalah "biaya proses manufaktur dengan beberapa keluaran (output) yang berbeda". Biaya yang timbul dalam proses produksi mencakup bahan langsung, tenaga kerja langsung, dan overhead pabrik. Dengan memproses satu bahan baku yang sama dan memunculkan dua produk, tahap pemrosesan kedua produk ini dipisahkan disebut titik pisah (split-off point). Biaya pemerosesan yang terjadi sebelum titik pisah disebut biaya gabungan.

Produk bersama dan karakteristik sifat produk bersama menurut Mursyidi (2010:152) produk bersama (joint product) adalah beberapa jenis produk yang dihasilkan dari bahan baku, tenaga kerja, dan biaya overhead yang sama dengan satu kali proses produksi. Pengertian ini memberikan gambaran bahwa sifat dari produk bersama yaitu, dihasilkan dari biaya produk bersama, dihasilkan dalam satu kali proses produksi, pada umumnya merupakan produk yang menjadi tujuan utama usaha perusahaan, produk-produk tersebut mempunyai nilai ekonomi yang relatif seimbang sesuai dengan kualitasnya, dan tidak dapat dinyatakan sebagai limbah industri apabila produk tersebut tidak laku dijual.

Menurut Surjadi (2013:66) produk bersama (joint product) adalah "dua produk atau lebih yang diproduksi secara serentak dengan serangkaian proses atau dengan proses gabungan". Jumlah dan harga jual tiap-tiap produk bersama ini relatif sama sehingga tidak ada dari produk-produk yang dihasilkan tersebut dianggap sebagai produk utama (main product) ataupun produk sampingan. Karakteristik joint product yaitu, produk bersama atau co-product merupakan tujuan utama kegiatan produksi, harga jual produk bersama atau co-product relatif tinggi bila dibandingkan dengan produk sampingan yang dihasilkan pada saat bersama, dalam mengelola produk bersama tertentu, produsen tidak dapat menghindarkan diri untuk menghasilkan semua jenis produk bersama, jika ia memproduksi hanya salah satu di antara produk bersama tersebut.

Menurut Mursyidi (2010) penentuan harga pokok produksi untuk masing-masing jenis produk yang dihasilkan dalam satu kali proses produksi dapat dilakukan dengan cara alokasi, dengan menggunakan salah satu dari metode-metode berikut.

Pertama metode nilai jual masingmasing jenis produk, dalam metode ini biaya bersama dialokasikan ke masingmasing jenis produk atas dasar total nilai jual masing-masing produk. Oleh karena itu metode ini hanya dapat digunakan apabila harga jual masingmasing jenis produk dapat ditentukan / diketahui sebelum produk tersebut dijual. Harga jual produk bersama terkadang sudah dapat ditentukan pada saat titik pisah, namun dapat ditentukan setelah dilakukan proses lebih lanjut. Dalam penerapan metode ini terdapat dua variasi berdasarkan kondisi produk bersama tersebut, (a) nilai pasar produk 
bersama diketahui pada titik pemisahan produk. Jika nilai pasar diketahui pada titik pisah produk, total biaya bersama dialokasikan diantara produk bersama dengan membagi total nilai pasar tiap produk yang dihasilkan dengan total nilai pasar semua produk yang dihasilkan sehingga diketemukan ratio individu dari nilai pasar terhadap total nilai pasar. Ratio inilah yang dikalikan dengan total biaya bersama. Dalam rumus alokasi biaya bersama untuk tiap produk sama dengan total biaya nilai pasar tiap produk dibagi dengan total nilai pasar semua produk dan dikalikan dengan biaya bersama. (b) nilai pasar produk bersama tidak diketahui pada titik pemisah produk / nilai pasar diketahui setelah titik pisah proses, nilai pasar pada titik pisah produk mungkin tidak diketahui, khususnya apabila tambahan proses pengolahan produksi diperlukan untuk menjadikan produk bersangkutan berada pada kondisi siap untuk dijual. Untuk itu perlu dilakukan sedikit modifikasi atas rumus yang disajikan diatas dengan sebuah nilai pasar yang hipotesis pada titik pisah produk mesti dihitung. Nilai pasar yang hipotesis itu ditentukan dengan mengurangi tambahan biaya untuk pemrosesan dari nilai pasar dari produk yang selesai. Dalam rumus alokasi biaya bersama untuk tiap produk sama dengan total nilai pasar hipotesis dibagi dengan total nilai pasar hipotesis semua produk dikalikan dengan biaya bersama.

Kedua metode rata-rata biaya per satuan, alokasi biaya bersama dengan metode rata-rata biaya satuan dapat digunakan apabila berbagai jenis produk dapat dihasilkan dalam satu proses produksi yang sama dan mempunyai ukuran yang sama atau dapat dipersamakan. Rumus untuk memperoleh alokasi biaya bersama dengan metode rata-rata biaya per satuan yaitu, alokasi biaya bersama sama dengan biaya per unit dikali jumlah unit dari tiap produk yang diproduksi (biaya per unit sama dengan total biaya tiap produk dibagi total jumlah unit yang diproduksi.
Ketiga metode rata-rata tertimbang, metode rata-rata biaya per satuan sering tidak dapat memecahkan masalah kesesuaian pembebanan biaya per satuan, karena untuk semua jenis produk dengan kualitas yang berbeda akan dibebani dengan biaya per satuan yang sama, padahal perbedaan jenis produk secara individual sangan mencolok, untuk kasus ini maka diperlukan suatu ukuran tertentu untuk dapat mempersamakan kadar dari produk-produk yang dihasilkan. Ukuran ini dikatakan sebagai angka penimbang (misalnya kadar gula dalam setiap jenis gula dengan kualitas yang berbeda). Angka penimbang ini ditentukan dimuka dengan suatu penelitian atau pengalaman. Rumus alokasi biaya bersama menggunakan metode rata-rata tertimbang adalah alokasi biaya bersama untuk tiap produk sama dengan total unit rataratatertimbang tiap produk dibagi total unit rata-rata tertimbang semua produk dikali biaya bersama.

Keempat metode satuan fisik, metode satuan fisik hanya dapat dipergunakan sebagai dasar alokasi biaya bersama jika produk yang dihasilkan mempunyai ukuran yang sama misalnya pon, gallon, dan ton. Jika tidak mempunyai ukuran yang sama, maka harus dicari koefisien ekuivalensinya untuk menentukan ukuran produk-produk yang dihasilkan menjadi ukuran yang sama. Metode ini sangat tepat dipergunakan pada perusahaan yang mengeksploitasi sumber alam, misalnya tambang batu bara, minyak dan gas, perkebunan dan perhutanan. Adapun rumus pengalokasian biaya bersama untuk metode satuan fisik yaitu, alokasi biaya bersama untuk tiap produk sama dengan total unit tiap produk dibagi total unit semua produk dikali biaya bersama. Metode-metode tersebut tidak dapat dianggap atau dipilih metode mana yang paling tepat, karena kerugian yang terjadi karena menggunakan suatu metode alokasi biaya bersama untuk satu jenis produk 
akan tertutupi oleh keuntungan jenis produk yang lainnya

Untuk mengetahui harga pokok produksi pada perusahaan yang menghasilkan produk bersama, perlu diketahui dasar alokasi biaya bersama pada setiap produk baik jumlah persatuan maupun secara keseluruhan. Hal ini penting dilakukan karena manajemen biasanya ingin mengetahui besarnya kontribusi tiap-tiap produk bersama tersebut terhadap seluruh penghasilan perusahaan, dengan demikian perusahaan dapat mengetahui dari beberapa produk yang dihasilkan tersebut, jenis mana yang menguntungkan atau jenis apa yang perlu didorong pemasarannya (Surjadi, 2013). Dalam mengevaluasi profitabilitas produk bersama tertentu pembuat keputusan harus memahami bahwa profitabilitas produk ditentukan terutama oleh metode yang digunakan dalam mengalokasikan biaya bersama dan bahwa proses alokasi selalu bersifat manasuka sampai batas yang tidak terduga (Raiborn dan Michael, 2011). Apabila dalam menghasilkan produk bersama tidak dilakukan perhitungan pengalokasian biaya bersama maka perusahaan yang menghasilkan produk bersama pada umumnya menghadapi masalah pemasaran berbagai macam produknya karena tiap-tiap produk tentu mempunyai masalah pemasaran dan harga jual yang berbeda-beda (Surjadi, 2013) dan juga perusahaan tidak dapat membedakan jenis produk yang dihasilkan berdasarkan kualitas, bentuk fisik, dan lain sebagainya (Mursyidi, 2010).

UD. Bali Busana Garment merupakan salah satu perusahaan yang memproduksi berbagai macam pakaian yang berlokasi di Jalan Raya Munggu, gang Cendrawasih, Perumahan Permata Selingsing blok A no. 27, Badung. Kegiatan produksi perusahaan ini mengelola berbagai jenis kain menjadi produk jadi dan hasil produk tersebut merupakan barangbarang dengan tujuan ekspor maupun impor. UD. Bali Busana Garment memproduksi barang lebih dari satu jenis produk. Hal ini disebabkan oleh minat akan pakaian saat ini baik wanita maupun pria tidak lagi sebagai alat penutup tubuh, tetapi juga sebagai alat prestise dan pemuas akan rasa seni, sehingga menuntut industri Garment untuk memproduksi atau menghasilkan berbagai macam produk.

Berdasarkan hasil penelitian awal yang peneliti lakukan pada UD. Bali Busana Garment, dalam menentukan harga pokok produksi khususnya produk bersama, perusahaan masih belum paham dalam mengklasifikasi biaya bersama pada masing-masing produk, sehingga sering terjadi kesalahan dalam pengalokasian biaya bersama. Seperti menetapkan biaya bahan baku yang sama pada masingmasing produk yang belum memperhitungkan biaya pengiriman dari masing-masing produk selama proses produksi. Selain itu pembagian biaya penggunaan mesin secara langsung pada saat proses produksi belum sesuai pembebanannya pada ketiga produk bersama. Perusahaan masih belum menerapkan metode pengalokasian biaya bersama terhadap ketiga produk bersama yang dihasilkan, sehingga masih terdapat biaya-biaya yang kurang tepat perhitungannya menjadi biaya yang dikeluarkan oleh produk tersebut saat diproduksi. Dengan permasalahan ini tentunya ada ketidak sesuaian dalam penentuan harga pokok produk khususnya pada saat memproduksi produk bersama, sehingga tidak diketahui secara jelas biaya-biaya yang dikeluarkan pada masing-masing produk dan harga pokok produksi sesungguhnya. Hal ini akan mengakibatkan manajemen pada perusahaan tidak bisa mengetahui besarnya kontribusi tiap-tiap produk bersama secara tepat. Sehingga perlu dilakukan perhitungan alokasi biaya bersama dengan metode pengalokasian biaya bersama dalam penetapan harga pokok produk yang tepat.

Berdasarkan uraian di atas, maka penulis melakukan penelitian dengan 
judul pengalokasian biaya bersama dalam penentuan harga pokok produksi pada UD. Bali Busana Garment Tahun 2016.

\section{METODE}

Penelitian ini menggunakan analisis deskriptif kuantitatif yaitu analisis yang menyajikan data yang berupa angka pada variabel yang diteliti, sesuai dengan persoalan yang dipecahkan sehingga diperoleh gambaran mengenai masalah pengalokasian biaya bersama dalam penentuan harga pokok produksi di UD. Bali Busana Garment. Penelitian ini dilakukan untuk mengetahui pengalokasian biaya bersama dalam penentuan harga pokok produksi pada UD. Bali Busana Garment.

Subyek dalam penelitian ini adalah perusahaan UD. Bali Busana Garment. Obyek dalam penelitian ini adalah penerapan alokasi biaya bersama dalam menentukan harga pokok produksi.

Metode pengumpulan data yang digunakan dalam penelitian ini menggunakan dokumentasi. Dokumentasi digunakan untuk pengumpulan data dengan melihat catatan dan dokumen-dokumen perusahaan berupa jumlah biaya seperti, daftar gaji karyawan, jumlah produksi barang, jenis produksi (katalog), dan data yang berkaitan dengan penelitian ini .

Analisis data yang digunakan adalah teknik analisis kuantitatif. Analisis kuantitatif merupakan cara untuk menganalisis data yang berupa angka-angka yang menyangkut tentang pengalokasian biaya bersama dalam penentuan harga pokok produksi. Menurut Mursyidi (2010:160) penentuan harga pokok produksi untuk masingmasing produk bersama yang dihasilkan dapat dilakukan dengan cara alokasi, dengan menggunakan salah satu dari metode-metode berikut (a) metode nilai jual masing-masing jenis produk, (b) metode rata-rata biaya per satuan, (c) metode rata-rata tertimbang, (d) metode satuan fisik, dalam penelitian ini peneliti akan menerapkan salah satu metode pengalokasian biaya bersama yaitu metode rata-rata biaya per satuan pada ketiga produk bersama yang dihasilkan dengan rumus, alokasi biaya bersama sama dengan biaya per unit dikali jumlah unit dari tiap produk yang diproduksi (biaya per unit sama dengan total biaya tiap produk dibagi total jumlah unit yang diproduksi (Mursyidi, 2010).

\section{HASIL DAN PEMBAHASAN Hasil}

UD. Bali Busana Garment merupakan salah satu perusahaan yang memproduksi berbagai macam pakaian. Kegiatan produksi perusahaan ini mengolah jenis kain yang menghasilkan barang lebih dari satu jenis produk. Dalam pengalokasian biaya bersama dilakukan perhitungan total dari seluruh biaya yang dikeluarkan. Proses pengolahan produk bersama menghasilkan tiga macam jenis produk yaitu singlet, jaket, dan top. Biaya bersama adalah penjumlahan biaya yang terdiri dari biaya bahan baku, biaya tenaga kerja langsung, dan biaya overhead pabrik yang sama dalam satu kali proses produksi yang menghasilkan berbagai jenis produk utama. Biaya bahan baku dari ketiga produk utama Bali Busana Garment adalah kain rayon motif. Perhitungan yang dilakukan dengan menjumlahkan seluruh biaya bahan baku yang dikeluarkan berdasarkan jumlah produk yang dihasilkan per bulan selama satu tahun. Biaya tenaga kerja yaitu upah dari seluruh tenaga kerja yang bekerja di UD. Bali Busana Garment meliputi bagian potong, bagian jahit, dan bagian packing. Perhitungan yang dilakukan berdasarkan jumlah tenaga kerja dan jumlah produk per bulan selama satu tahun. Biaya overhead pabrik mencakup biaya produksi lainnya seperti biaya listrik, biaya air, biaya bahan penolong, biaya pengiriman bahan dan biaya penyusutan mesin. Perhitungan yang dilakukan berdasarkan jumlah produk yang dihasilkan per bulan selama satu tahun. 
Dasar alokasi biaya bersama yang akan dilakukan untuk menentukan biaya bersama menggunakan metode ratarata satuan. Biaya produksi yang dikeluarkan selama satu tahun sebesar Rp. 1.005.317.733,00 yang terdiri dari biaya bahan baku sebesar Rp. 181.350.000,00 biaya tenaga kerja sebesar Rp.795.300.000,00 dan biaya overhead pabrik sebesar Rp. 28.667.733,00,00. Produk selesai yang dihasilkan dari seluruh biaya yang dikeluarkan adalah produk singlet 1600 buah, produk jaket 1400 buah, produk top 1750 buah.

\section{Dalam menentukan harga pokok} dari masing-masing produk yang dihasilkan, maka dilakukan perhitungan biaya harga pokok produksi. Cara menentukan harga pokok ketiga macam produk utama pada UD. Bali Busana Garment dengan (a) menghitung unsurunsur biaya bersama yaitu biaya bahan baku, biaya tenaga kerja, dan biaya overhead pabrik, (b) menghitung biaya bahan baku dan biaya tenaga kerja sesuai dengan masing-masing produk, (c) menghitung biaya overhead dihitung seragam dari perbandingan jumlah masing-masing produk, dengan rumus jumlah per unit yang dihasilkan per produk dibagi dengan total seluruh produk yang dihasilkan dikali seratus persen. Untuk produk singlet dibebankan sebesar 34\%, dan untuk produk jaket dibebankan sebesar 29\%, dan produk top dibebankan sebesar $37 \%$. Untuk menghitung harga pokok dari masing-masing produk, jumlah biaya produk utama dibagi dengan jumlah produk utama yang dihasilkan oleh perusahaan.

Pada bulan Januari dalam satu kali proses produksi telah dihasilkan produk singlet sebanyak 125 buah dengan biaya bahan baku sebesar Rp. $3.750 .000,00$, biaya tenaga kerja $\mathrm{Rp}$. 20.625.000,00 dan biaya overhead pabrik sebesar Rp. 980.340,00 sehingga total seluruh produksi untuk produk singlet sebesar Rp. 25. $355.340,00$. Maka harga pokok produksi produk singlet Rp. 202.842,00 per buah. Untuk produk jaket 100 buah biaya bahan baku yang digunakan sebesar Rp. 3.900.000,00, biaya tenaga kerja Rp. 16.700.000,00, dan biaya overhead pabrik Rp. 885.290,00 sehingga total seluruh produksi untuk produk jaket sebesar Rp. 21.485.290,00 per buah. Maka harga pokok produksi produk jaket Rp. 214.852,00. Untuk produk top 250 buah biaya bahan baku yang digunakan sebesar Rp. 11.250.000,00, biaya tenaga kerja $\mathrm{Rp}$. $42.500 .000,00$ dan biaya overhead pabrik sebesar Rp. 1.160.370,00 sehingga total seluruh produksi produk top sebesar Rp. 54.910.370,00. Maka harga pokok produksi Rp. 219.641,00 per buah.

Pada bulan Februari dalam satu kali proses produksi telah dihasilkan produk singlet sebanyak 200 buah dengan biaya bahan baku sebesar Rp. $6.000 .000,00$, biaya tenaga kerja Rp. $33.000 .000,00$ dan biaya overhead pabrik sebesar Rp. 805.308,00 sehingga total seluruh produksi untuk produk singlet sebesar Rp. 39.805.308. Maka harga pokok produksi Rp. 199.026,00 per buah. Untuk produk top 100 buah biaya bahan baku yang digunakan sebesar Rp. 4.500.000,00, biaya tenaga kerja Rp. 417.000.000,00 dan biaya overhead pabrik sebesar Rp. 773.394,00 sehingga total seluruh produksi produk top sebesar Rp. 22.273.394,00. Maka harga pokok produksi Rp. 222.733,00 per buah.

Pada bulan Maret dalam satu kali proses produksi telah dihasilkan produk produk jaket 100 buah biaya bahan baku yang digunakan sebesar Rp. $3.900 .000,00$, biaya tenaga kerja $\mathrm{Rp}$. 16.700.000,00, dan biaya overhead pabrik Rp. 541.292,00 sehingga total seluruh produksi untuk produk jaket sebesar Rp. 21.141.292,00. Maka harga pokok produksi Rp. 211.412,00 Untuk produk top 50 buah biaya bahan baku yang digunakan sebesar Rp. 2.250.000,00, biaya tenaga kerja $\mathrm{Rp}$. $8.500 .000,00$ dan biaya overhead pabrik sebesar Rp. 533.476,00 sehingga total seluruh produksi produk top sebesar Rp. 11.283.476,00. Maka 
harga pokok produksi Rp. 225.669,00 per buah.

Pada bulan April dalam satu kali proses produksi telah dihasilkan produk singlet sebanyak 100 buah dengan biaya bahan baku sebesar Rp. $3.000 .000,00$, biaya tenaga kerja $\mathrm{Rp}$. $16.500 .000,00$ dan biaya overhead pabrik sebesar Rp. 695.074,00 sehingga total seluruh produksi untuk produk singlet sebesar Rp. 20. 195.074. maka harga pokok produksi Rp. 201.950,00 per buah. Untuk produk jaket 150 buah biaya bahan baku yang digunakan sebesar Rp. 5.850.000,00, biaya tenaga kerja Rp. 25.050.000,00, dan biaya overhead pabrik Rp. $733.269,00$ sehingga total seluruh produksi untuk produk jaket sebesar Rp. 31.633.269,00. Maka harga pokok produksi Rp. 210.888,00 per buah. Untuk produk top 50 buah biaya bahan baku yang digunakan sebesar Rp. 2.250.000,00, biaya tenaga kerja Rp. $8.500 .000,00$ dan biaya overhead pabrik sebesar Rp. 696.757,00 sehingga total seluruh produksi produk top sebesar Rp. 11.446.757,00. Maka harga pokok produksi Rp. 228.935,00 per buah.

Pada bulan Mei dalam satu kali proses produksi telah dihasilkan produk singlet sebanyak 150 buah dengan biaya bahan baku sebesar Rp. 4.500.000,00, biaya tenaga kerja $\mathrm{Rp}$. $24.750 .000,00$ dan biaya overhead pabrik sebesar Rp. 1.012.538,00 sehingga total seluruh produksi untuk produk singlet sebesar Rp. 30.262.538,00. Maka harga pokok produksi Rp. 201.950,00 per buah. Untuk produk jaket 200 buah biaya bahan baku yang digunakan sebesar Rp. 7.800.000,00, biaya tenaga kerja Rp. 33.400.000,00, dan biaya overhead pabrik Rp. 1.041.253,00 sehingga total seluruh produksi untuk produk jaket sebesar Rp. 42.241.253,00. Maka harga pokok produksi Rp. 211.206,00 per buah. Untuk produk top 150 buah biaya bahan baku yang digunakan sebesar Rp. 6.750.000,00, biaya tenaga kerja Rp. $25.500 .000,00$ dan biaya overhead pabrik sebesar Rp.
1.082.909,00,00 sehingga total seluruh produksi produk top sebesar Rp. 33.332.909,00. Maka harga pokok produksi Rp. 222.219,00 per buah.

Pada bulan Juni dalam satu kali proses produksi telah dihasilkan produk singlet sebanyak 175 buah dengan biaya bahan baku sebesar Rp. $5.250 .000,00$, biaya tenaga kerja $\mathrm{Rp}$. 28.875.000,00 dan biaya overhead pabrik sebesar Rp. 963.561,00 sehingga total seluruh produksi untuk produk singlet sebesar Rp. 35.088.561,00. Maka harga pokok produksi Rp. 200.506,00 per buah. Untuk produk top 200 buah biaya bahan baku yang digunakan sebesar $\mathrm{Rp}$. $9.000 .000,00$, biaya tenaga kerja $\mathrm{Rp}$. $34.000 .000,00$ dan biaya overhead pabrik sebesar Rp. 1.058.111,00 sehingga total seluruh produksi produk top sebesar Rp. 44.058.111,00. Maka harga pokok produksi Rp. 220.290,00 per buah.

Pada bulan Juli dalam satu kali proses produksi telah dihasilkan produk produk top 100 buah biaya bahan baku yang digunakan sebesar Rp. 4.500.000,00, biaya tenaga kerja $\mathrm{Rp}$. $17.000 .000,00$ dan biaya overhead pabrik sebesar Rp. 507.753,00 sehingga total seluruh produksi produk top sebesar Rp. 22.007.753,00. Maka harga pokok produksi Rp. 220.077,00 per buah.

Pada bulan Agustus dalam satu kali proses produksi telah dihasilkan produk singlet sebanyak 100 buah dengan biaya bahan baku sebesar Rp. $3.000 .000,00$, biaya tenaga kerja $\mathrm{Rp}$. $16.500 .000,00$ dan biaya overhead pabrik sebesar Rp. 1.126.058,00 sehingga total seluruh produksi untuk produk singlet sebesar Rp. 20.626.058,00. Maka harga pokok produksi Rp. 206.260,00 per buah. Untuk produk jaket 250 buah biaya bahan baku yang digunakan sebesar Rp. 9.750.00,00, biaya tenaga kerja Rp. $41.750 .000,00$, dan biaya overhead pabrik Rp. 1.243.873,00 sehingga total seluruh produksi untuk produk jaket sebesar Rp. 52.743.873,00. Maka harga pokok produksi Rp. 210.975,00 
per buah. Untuk produk top 300 buah biaya bahan baku yang digunakan sebesar Rp. 13.500.000,00, biaya tenaga kerja Rp. $51.000 .000,00$ dan biaya overhead pabrik sebesar Rp. $1.400 .769,00$ sehingga total seluruh produksi produk top sebesar Rp. 65.900.769,00. Maka harga pokok produksi Rp. 219.669,00 per buah.

Pada bulan September dalam satu kali proses produksi telah dihasilkan produk singlet sebanyak 250 buah dengan biaya bahan baku sebesar Rp. 7.500.000,00, biaya tenaga kerja Rp. 41.250.000,00 dan biaya overhead pabrik sebesar Rp. 1.442.825,00 sehingga total seluruh produksi untuk produk singlet sebesar Rp. 50.192.825,00. Maka harga pokok produksi Rp. 200.771,00 per buah. Untuk produk jaket 300 buah biaya bahan baku yang digunakan sebesar Rp. $11.700 .000,00$, biaya tenaga kerja Rp. 50.100.000,00, dan biaya overhead pabrik Rp. 1.510.263,00 sehingga total seluruh produksi untuk produk jaket sebesar Rp. 63.310.263,00. Maka harga pokok produksi Rp. 211.034,00 per buah. Untuk produk top 250 buah biaya bahan baku yang digunakan sebesar Rp. 11.250.000,00, biaya tenaga kerja Rp. 42.500.000,00 dan biaya overhead pabrik sebesar Rp. 1.571.163,00 sehingga total seluruh produksi produk top sebesar Rp. 55.321.163,00. Maka harga pokok produksi Rp. 221.284,00 per buah.

Pada bulan Oktober dalam satu kali proses produksi telah dihasilkan produk singlet sebanyak 150 buah dengan biaya bahan baku sebesar Rp. 4.500.000,00, biaya tenaga kerja Rp. $24.750 .000,00$ dan biaya overhead pabrik sebesar Rp. 781.066,00 sehingga total seluruh produksi untuk produk singlet sebesar Rp. 30.031.066,00. Maka harga pokok produksi Rp. 200.207,00 per buah. Untuk produk jaket 150 buah biaya bahan baku yang digunakan sebesar Rp. 5.850.000,00, biaya tenaga kerja Rp. 25.050.000,00, dan biaya overhead pabrik Rp. 781.821,00 sehingga total seluruh produksi untuk produk jaket sebesar Rp. 31.681.821,00. Maka harga pokok produksi Rp. 211.212,00 per buah.

Pada bulan November dalam satu kali proses produksi telah dihasilkan produk singlet sebanyak 300 buah dengan biaya bahan baku sebesar Rp. 9.000.000.,00, biaya tenaga kerja $\mathrm{Rp}$. $49.500 .000,00$ dan biaya overhead pabrik sebesar Rp. 1.198.496,00 sehingga total seluruh produksi untuk produk singlet sebesar Rp. 59.698.496,00. Maka harga pokok produksi Rp. 198.994,00 per buah. Untuk produk jaket 50 buah biaya bahan baku yang digunakan sebesar Rp. $1.950 .000,00$, biaya tenaga kerja Rp. 8.350.000,00, dan biaya overhead pabrik Rp. 848.276,00 sehingga total seluruh produksi untuk produk jaket sebesar Rp. 11.148.276,00. Maka harga pokok produksi Rp. 222.965,00 per buah. Untuk produk top 200 buah biaya bahan baku yang digunakan sebesar Rp. 9.000.000,00, biaya tenaga kerja Rp. 34.000.000,00 dan biaya overhead pabrik sebesar Rp. 1.188.628,00 sehingga total seluruh produksi produk top sebesar $\mathrm{Rp}$. 44.188.628,00. Maka harga pokok produksi Rp. 220.943,00 per buah.

Pada bulan Desember dalam satu kali proses produksi telah dihasilkan produk singlet sebanyak 50 buah dengan biaya bahan baku sebesar Rp. $1.500 .000,00$, biaya tenaga kerja $\mathrm{Rp}$. $8.250 .000,00$ dan biaya overhead pabrik sebesar Rp. 661.272,00 sehingga total seluruh produksi untuk produk singlet sebesar Rp. 10.411.272,00. Maka harga pokok produksi Rp. 208.225,00 per buah. Untuk produk jaket 100 buah biaya bahan baku yang digunakan sebesar Rp. 3.900.000,00, biaya tenaga kerja Rp. 16.700.000,00, dan biaya overhead pabrik Rp. 682.232,00 sehingga total seluruh produksi untuk produk jaket sebesar Rp 21. 282.232,00. Maka harga pokok produksi Rp. 212.822,00 per buah. Untuk produk top 100 buah biaya bahan baku yang digunakan sebesar Rp. 4.500.000,00, biaya tenaga kerja Rp. $17.000 .000,00$ dan biaya 
overhead pabrik sebesar Rp. $760.296,00$ sehingga total seluruh produksi produk top sebesar Rp. 22.260.296,00. Maka harga pokok produksi Rp. 222.602,00 per buah.

\section{Pembahasan}

Dari data yang diperoleh maka, dapat dianalisis penerapan pengalokasian biaya bersama dalam menentukan harga pokok produksi pada UD. Bali Busana Garment pada tahun 2016. Dalam membebankan biaya produksi perusahaan diharapkan dapat memahami dasar alokasi biaya yang sudah ditentukan baik dalam pencatatannya maupun dalam penggolongannya. Tujuan dari alokasi biaya untuk memberikan informasi kepada manajemen dalam penyusunan laporan keuangan maupun kepentingan dalam mengambil keputusan (Mursyidi, 2010). Adapun dalam penggolongannya biaya pengiriman bahan baku dan biaya penyusutan mesin pada awalnya tidak dialokasikan pada produk bersama, biaya produksi mencangkup seluruh biaya yang kaitannya dengan proses produksi dan harus ikut diperhitungkan karena digunakan dalam kegiatan produksi atau oprasional perusahaan (Mulyadi, 2009), misalnya gedung yang digunakan sebagai tempat untuk melaksanakan kegiatan produksi, biaya pembelian bahan baku, dan peralatan mesin digunakan untuk berproduksi..

Dengan mengalokasikan biaya pengiriman bahan baku dan biaya penyusutan mesin maka biaya overhead pabrik sesungguhnya mengalami perubhan, sehingga ada perbedaan harga pokok produksi sebelum dan sesudah diperhitungkan biaya pengiriman bahan baku dan biaya penyusutan mesin dengan metode alokasi biaya bersama pada UD. Bali Busana Garment tahun 2016. Setelah diketahui besarnya biaya bahan baku, biaya tenaga kerja dan biaya overhead pabrik sesungguhnya, dapat diperhitungkan harga pokok dan alokasi biaya bersama pada tiap-tiap produk.

Dari perhitungan yang dilakukan tiap bulan selama satu tahun maka diperolehlah besarnya harga pokok dari produk singlet pada bulan Januari sebesar Rp.202.842,00 dari sebelumnya sebesar Rp. 201.063, pada bulan Februari Rp. 199.026,00 dari sebelumnya Rp. 197.946,00, pada bulan April Rp. 201.950,00 dari sebelumnya Rp. 199.789,00, pada bulan Mei Rp. 201.750,00 dari sebelumnya sebesar Rp. 200.260,00, pada bulan Juni Rp. 200.506,00 dari sebelumnya Rp. 200.980,00, pada bulan Agustus Rp. 206.260,00 dari sebelumnya Rp. 203.971,00, pada bulan September Rp. 200.771 dari sebelumnya Rp. 200.638,00, pada bulan Oktober Rp. 200.207 dari sebelumnya Rp. 198.765,00, pada bulan November Rp. 198.994,00 dari sebelumnya Rp. 198.244,00, dan pada bulan Desember Rp. 208.225,00 dari sebelumnya Rp. 207.962,00.

Harga pokok dari produk jaket pada bulan Januari Rp. 214.852,00. dari sebelumnya Rp. 212.955,00, pada bulan Maret Rp. 211.412,00 dari sebelumnya Rp. 212. 633,00, pada bulan April Rp. 210.888,00 dari sebelumnya Rp. 209.659,00, pada bulan Mei Rp. 211.206 dari sebelumnya Rp. 210.253,00, pada bulan Agustus Rp. $210.975,00$ dari sebelumnya Rp. 210.194,00, pada bulan September Rp. 211.034,00 dari sebelumnya Rp. 211. 038,00, pada bulan Oktober Rp. $211.212,00$ dari sebelumnya Rp. 209.982,00, pada bulan November Rp. 222.965,00 dari sebelumnya Rp. 219.127,00, dan pada bulan Desember Rp. 212.822 dari sebelumnya Rp. 213.005,00.

Harga Pokok produk top pada bulan Januari Rp. 219.641,00 dari sebelumnya Rp. 218.673,00, pada bulan Februari Rp. 222.733,00 dari sebelumnya Rp. 220.383,00, pada bulan Maret Rp. 225.669,00 dari sebelumnya Rp. 227.118,00, pada bulan April Rp. 228.935,00 dari sebelumnya Rp 224.230,00, pada bulan Mei Rp. 222.219,00 dari sebelumnya Rp. 220.598,00, pada bulan Juni Rp. 220.290,00 dari sebelumnya Rp. 220.609,00, pada bulan Juli Rp. 
220.077,00 dari sebelumnya Rp. 217.805,00, pada bulan Agustus Rp. $219.669,00$ dari sebelumnya Rp. $218.838,00$, pada bulan September Rp. 221.284,00 dari sebelumnya Rp. 221.069,00, pada bulan November Rp. 220.943,00 dari sebelumnya Rp. $219.718,00$, dan pada bulan Desember Rp. 222.602 dari sebelumnya Rp. 222.282,00. Setelah menetapkan harga pokok dari masing-masing produk bersama yang sesungguhnya maka manajemen perusahaan dapat mengetahui besarnya kontribusi dari tiap-tiap produk bersama sesungguhnya terhadap seluruh penghasilan perusahaan. Oleh karena itu penting bagi perusahaan untuk melakukan perhitungan harga pokok produksi secara tepat, baik dalam pencatatannya maupun penggolongan biayanya.

\section{SIMPULAN DAN SARAN Simpulan}

Bedasarkan hasil penelitian dan pembahasan, maka dapat disimpulkan bahwa penerapan pengalokasian biaya bersama pada UD. Bali Busana Garment dapat dilakukan. Hal ini disebabkan karena pada perusahaan sudah terdapat tiga unsur dasar dalam pengalokasian biaya bersama yaitu biaya bahan baku, biaya tenaga kerja, dan biaya overhead pabrik. Setelah diketahui besarnya biaya bahan baku, biaya tenaga kerja dan biaya overhead pabrik sesungguhnya, maka dapat dihitung seluruh biaya bersama yang dikeluarkan kepada ketiga produk yaitu singlet, jaket, dan top, sehingga diperoleh perbedaan harga pokok dari masing-masing produk per bulannya pada tahun 2016.

\section{Saran}

Adapun saran yang disampaikan sebagai berikut. Pertama dalam menghitung biaya bahan hendaknya perusahaan memperhitungkan biaya pengiriman bahan terlebih dahulu sehingga dapat mengetahui jumlah biaya bahan selama produksi dengan tepat yang dikeluarkan dalam kegiatan produksi untuk menentukan harga jual yang tepat.

Kedua dalam menghitung biaya overhead pabrik diharapkan perusahaan hendaknya memperhitungkan biaya penyusutan mesin sehingga dapat mengetahui jumlah biaya produksi yang dikeluarkan dalam kegiatan produksi untuk menentukan harga jual yang tepat.

Ketiga dalam penelitian ini diharapkan perusahaan dapat memahami tentang pengalokasian biaya bersama dalam menentukan harga pokok berbagai macam produk sehingga hasil penelitian ini dapat memberikan manfaat bagi perusahaan yang bersangkutan.

\section{DAFT AR PUSTAKA}

Bastian, Bustami dan Nurlela. 2010. Akuntansi Biaya. Yogyakarta: Graha IImu.

Dunia, Firdaus Ahmad dan Wasilah Abdullah. 2014. Akuntansi Biaya. Edisi Ke-3. Jakarta: Salemba Empat.

Fuad, Muhammad Dkk. 2006. Pengantar Bisnis. Jakarta: Gramedia Pustaka Utama.

Gilarso. 2003. Pengantar IImu Ekonomi Mikro Edisi Revisi. Yogyakarta: Kanisius.

Hanggana, Sri. 2006. Prinsip Dasar Akuntansi. Surakarta: Mediatama.

Kuswadi. 2008. Memahami Rasio-Rasio Keuangan Bagi Orang Awam. Jakarta: PT Elex Media Komputindo Kelompok Gramedia.

Maher. Michael W. Dan Edward Deakin .1997. Akuntansi Biaya. Edisi $\mathrm{Ke}-4$ Jilid 1. Penerjemah Herman Wibowo dan Adjat Djatnika. Jakarta: Erlangga.

Mulyadi. 2009. Akuntansi Biaya. Edisi Ke-5 Cetakan Sembilan. Yogyakarta: Sekolah Tinggi Ekonomi YKPN.

Mursyidi. 2010. Akuntansi Biaya Conventional Costing Just in Time, dan Activity-Based 
Costing. Bandung: PT Refika Aditama.

Prasetyo, Aries Heru. 2012. Permodelan Keuangan. Jakarta: PPM.

Raiborn, Cecily A. dan Michael R. Kinney. 2011. Akuntansi Biaya Dasar dan Perkembangan Buku Satu Edisi Tujuh. Penerjemah Biro Bahasa Alkemis. Jakarta: Salemba Empat.

Sugiri, Slamet. 2010. Akuntansi Manajemen. Yogyakarta: Sekolah Tinggi Ilmu Manajemen YKPN.

Surjadi, Lukman. 2013. Akuntansi Biaya. Jakarta: Permata Puri Media.

Widilestariningtyas, Ony dkk. 2012. Akuntansi Biaya. Yogyakarta: Graha IImu.

Widjajatunggal, Amin. 1997. Akuntansi Biaya. Jakarta: PT. Rineka Cipta.

Winwin, Yadiati dan Wahyudi Ilham. 2008. Pengantar Akuntansi Edisi Pertama. Yogyakarta: Graha IImu.

Witjaksono, Armanto. 2013. Akuntansi Biaya Edisi Revisi. Yogyakarta : Graha IImu. 